\title{
Exchange Rate Adjustment And Output In South-East Asia
}

Kamal P. Upadhyaya, University of New Haven, USA

Robert Rainish, University of New Haven, USA

Neetu Kaushik, University of New Haven, USA

Rabindra N. Bhandari, Westminster College, USA

\begin{abstract}
This paper studies the effect of currency devaluation on aggregate output level in South- East Asian countries using panel data from Thailand, Malaysia, Indonesia and the Philippines for a period from 1980 to 2010. An empirical model that includes monetary, fiscal and exchange rate variables is developed. Two versions of the model, one with real exchange rate and another with nominal exchange rate and foreign-to-domestic price ratio are estimated. An error correction model is developed and the time series properties of the panel data are diagnosed before estimating the model. The estimated results suggest that currency devaluations are contractionary in the short run and the intermediate run and this contractionary effect comes from the change in nominal exchange rate and not from the change in foreign-to-domestic price ratio.
\end{abstract}

Keywords: Currency Devaluation; South-East Asia; Panel Data; Cointegration; Error Correction Model

\section{INTRODUCTION}

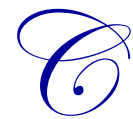

urrency devaluation is often considered a major tool in the stabilization of the foreign sector of an economy. It is argued that a devaluation or depreciation improves the terms of trade by raising the price of imported goods and services and lowering the price of exports, leading to an improvement in a country's trade balance. This improvement in the foreign sector expands aggregate output and employment in the overall economy.

Many argue that the expansionary effect of currency devaluation or depreciation is based on a very simplistic logic. According to them currency devaluation may not necessarily increase the level of output, particularly in developing countries. Instead, it can even have a contractionary effect. The contractionary effect can come from both the demand side as well as the supply side. For example, devaluation may lead to a negative real balance effect, resulting in lower levels of aggregate demand and output. In addition currency devaluation distributes income from the group with lower marginal propensity to save to the group with higher propensity to save through increases in the price level. This further reduces aggregate demand in the economy (Krugman and Taylor 1978; Lizondo and Montiel, 1989). Finally, if the export and import elasticities are very low then the trade balance (measured in terms of domestic currency) may deteriorate and lead to a recessionary effect in the economy. All or any one these cases suggest that a devaluation or depreciation can lead to a lower level of output and employment in an economy by reducing the aggregate demand.

Contractionary effects of exchange rate depreciation can also come through the supply side. Exchange rate depreciation raises the cost of imported inputs, leading to a decrease in aggregate supply. Additionally, it may raise the domestic interest rate and wage level through an increase in the price level. This may decrease aggregate supply in the economy.

The relationships between currency devaluation and output growth have been investigated by a number of studies, but the empirical findings are mixed. Gylfason and Schmid (1983), and Conolly (1983) find that currency devaluations have a positive effect on the economy. On the other hand, Gylfason and Risager (1984) and Branson 
(1986) find devaluation to be contractionary. Edwards (1986), has a widely-cited study based on pooled time-series cross-section data from 12 developing countries. He finds a small contractionary effect in the first year that becomes expansionary in the second year and neutral in the long run. Sawyer and Sprinkle (1987) using the new structuralists model simulated the short-run effects of devaluation in Mexico. Their simulated results indicated that devaluation, in general, improved the trade balance but contracted the domestic economy in Mexico. Using econometric methodology developed by Wickens and Breusch (1988), Upadhyaya (1999) finds that devaluation has a neutral effect in the long run.

Some recent studies have examined the impact of currency devaluation by incorporating real exchange rate directly or alternatively by decomposing the exchange rate effects into nominal exchange rate effect and the relative price level effect (foreign-to-domestic price ratio). For example, Upadhyaya and Upadhyay (1999) find that devaluation generally did not have any effect on output over any length of time in the six Asian countries studied, and any effect uncovered came from changes in relative price level, and not from nominal devaluation. In another study, Upadhyaya, Dhakal and Mixon (2000) found currency depreciations were usually contractionary in selected Latin American countries, and that the contractionary effect came from nominal exchange rate, not from the relative price level. Upadhyaya, Mixon and Bhandari (2004) reported short run expansionary effects on output in Greece and Cyprus between 1969 and 1998 that emanated from both nominal devaluation and changes in the relative price level.

The present study is based on the panel data from the following four South- East Asian countries namely Thailand, Malaysia, Indonesia and the Philippines. Given the fact that these countries currencies have been through devaluations (depreciation) in the 1990s it is hoped that this study will help shed some light on its impact on economy.

The organization of the paper is as follows. Section 2 outlines the methodology of the study and the data. The empirical findings are discussed in Section 3, and Section 4 presents a summary and conclusion.

\section{METHODOLOGY AND DATA}

Economic activity in a developing country is affected by a number of fiscal and monetary variables, particularly by the level of fiscal expenditure and the rate of change of the money supply (Edwards 1986, Khan and Knight 1981). Following this argument we include government expenditures and money supply as fiscal and monetary variables that explain the level of aggregate output. Following Upadhyaya and Upadhyay (1999) we use two approaches to examine the effect of a change in the exchange rate on output. The first one includes the change in the real exchange rate directly, which is consistent with the idea that a nominal change in the exchange rate influences output only if it leads to a change in the real exchange rate. This approach considers only the effect of a movement in real exchange rates and disregards the combination of nominal exchange rates and foreign-to-domestic price ratios that generate such a movement. If the price level changes at the same rate as the nominal exchange rate then the real exchange rate remains constant (and has no effect on the output level). This method, however, ignores any asymmetric influence that an initial change in the exchange rate may have on output vis-à-vis the effect of a gradual rise in the price level. Hence, an alternative model, including the nominal exchange rate (instead of the real exchange rate) and the relative price level is also estimated. This approach enables us to find out whether any effect originates from a change in the nominal exchange rate or from the relative price ratio.

Based on the above discussion the following empirical models are developed.

$$
\begin{aligned}
\log Y_{t}= & b_{0}+b_{1} \log G_{t}+b_{2} \log M S_{t}+b_{3} \log R E_{t}+b_{4} \log R E_{t-1} \\
& +b_{5} \log R E_{t-2}+b_{6} \log T O T_{t}+u_{1} \\
\log Y_{t}= & b_{0}+b_{1} \log G_{t}+b_{2} \log M S_{t}+b_{3} \log E_{t}+b_{4} \log E_{t-1}+b_{5} \log E_{t-2} \\
& +b_{6} \log R E P R_{t}+b_{7} \log R E P R_{t-1}+b_{8} \log R E P R_{t-2}+b_{9} \log T O T_{t}+u_{2}
\end{aligned}
$$

In equations (1) and (2), $Y$ is the aggregate output, $G$ is government expenditure, $M S$ is the money supply (all in 
2000 prices), $E$ is the nominal exchange rate of domestic currency to U.S. dollars, relative price ration (foreign to domestic price ration). $G$ and $M S$ respectively represent the fiscal and monetary policy variables. World price index is used as the foreign price level. The real exchange rate $R E$ is defined as $\left(E P^{*} / P\right)$ and $\left(P^{*} / P\right)$ is the foreign to domestic price ratio (relative price level). Finally, $u$ is the random error term. TOT is the terms trade defined as import price index divided by the export price index.

Since an increase in government expenditure is assumed to be expansionary, the coefficient of $\log G$ is expected to be positive. Likewise, the coefficient of $\log M S$ is also expected to be positive as an increase in the money supply is considered to be expansionary to the economy. Since a favorable term of trade helps to improve the trade balance as well as the level of output and employment the coefficient of $\log T O T$ is expected to carry a positive sign. The coefficient of the real exchange rate, $\log R E$, captures the effect of a change in the exchange rate on output and is the main concern of the present study. If it is negative, and statistically significant, ceteris paribus, any change in exchange rates negatively affect the real output. In that case, devaluations (exchange rate depreciations) are contractionary to the economy. However, if the coefficient of $\log R E$ is positive and significant any exchange rate depreciation is considered expansionary to the economy. If it is insignificant then devaluation is neutral to output growth. A change in the exchange rate in the current period can affect output with a lag; therefore lagged values of the real exchange rates are also included in the estimation of the regression model. Inclusion of lagged values is also important because any devaluation can have different effects for different time horizons. For example, Edwards (1986) finds that exchange rate depreciations are contractionary in the short run, expansionary in the medium run, and neutral in the long run.

As mentioned earlier, this study is based on panel data from four South-East Asian countries: Thailand, Malaysia, Indonesia and the Philippines. A panel data series is constructed using the annual time series data from 1980 to 2010. All the variables are measured in 2000 price. They are derived from World Development Indicators.

\section{ESTIMATION AND EMPIRICAL RESULTS}

It is important to test the stationarity of the data series since the use of non-stationary data can produce spurious results. To ensure the stationarity of the panel data, Levin, Lin and Chu (2002), Breitung (2000), and Im, Pesaran and Shin (2003) unit root tests are utilized. As reported in Table 1, the data series are found to be nonstationary at level but are found stationary at the first difference level.

Table 1: Panel Unit Root Test

\begin{tabular}{|c|c|c|c|c|c|c|}
\hline & \multicolumn{2}{|c|}{ Levin, Lin \& Chu } & \multicolumn{2}{|c|}{ Breitung t-stat } & \multicolumn{2}{|c|}{ Im, Pesaran \& Shin } \\
\hline Variable & Level & FD & Level & FD & Level & FD \\
\hline $\log E$ & 0.06 & $-5.99 * * *$ & -0.47 & $-5.04 *$ & 0.02 & $-7.46 * * *$ \\
\hline $\log R E$ & 1.52 & $-5.37 * * *$ & $-2.17 * *$ & $-6.53 * * *$ & $-1.59 *$ & $-7.76 * * *$ \\
\hline $\log R E P R$ & -0.53 & $-5.70 * * *$ & 0.42 & $-4.34 * * *$ & 0.12 & $-3.66 * * *$ \\
\hline $\log G$ & 3.82 & $-5.08 * * *$ & 1.63 & $-3.02 * * *$ & 2.99 & $-4.37 * * *$ \\
\hline $\log M S$ & 2.93 & $-3.08 * * *$ & 9.15 & -0.32 & 6.47 & $-4.88 * * *$ \\
\hline $\log$ TOT & 3.44 & $-17.2 * * *$ & -1.06 & $-1.60 *$ & 0.22 & $-15.3 * * *$ \\
\hline $\log Y$ & 0.80 & $-5.78 * * *$ & 1.04 & $-5.27 * * *$ & 1.19 & $-4.38 * * *$ \\
\hline
\end{tabular}

$* * *, * *, *$ significant respectively at $1 \%, 5 \%$, and $10 \%$ critical level.

Table 2: Pedroni's Panel Cointegration Test

(Variables: $\log$ Y, $\log$ G, $\log$ MS, $\log$ RE, $\log$ TOT)

\begin{tabular}{|l|c|c|c|c|}
\hline & statistics & probability & weighted statistics & probability \\
\hline Panel v-statistics & -0.61 & 0.33 & -0.73 & 0.03 \\
\hline Panel rho-statistics & 2.02 & 0.05 & 2.25 & 0.03 \\
\hline Panel PP-statistics & 1.65 & 0.10 & 1.88 & 0.07 \\
\hline Panel ADF- statistics & 1.87 & 0.07 & 2.27 & 0.03 \\
\hline & statistics & probability & & \\
\hline Group rho-statistics & 3.01 & 0.004 & & \\
\hline Group PP-statistics & 2.45 & 0.020 & & \\
\hline Group ADF-statistics & 3.02 & 0.004 & & \\
\hline
\end{tabular}


Table 3: Pedroni's Panel Cointegration Test

(Variables: $\log$ Y, $\log$ G, $\log$ MS, $\log$ E, $\log$ REPR, $\log$ TOT)

\begin{tabular}{|l|c|c|c|c|}
\hline & statistics & probability & weighted statistics & probability \\
\hline Panel v-statistics & -0.41 & 0.37 & -1.62 & 0.10 \\
\hline Panel rho-statistics & 1.21 & 0.19 & 2.92 & 0.01 \\
\hline Panel PP-statistics & -0.90 & 0.26 & 2.26 & 0.03 \\
\hline Panel ADF-statistics & 1.21 & 0.19 & 3.44 & 0.00 \\
\hline & statistics & probability & & \\
\hline Group rho-statistics & 3.48 & 0.00 & & \\
\hline Group PP-statistics & 2.91 & 0.01 & & \\
\hline Group ADF statistics & 4.46 & 0.00 & & \\
\hline
\end{tabular}

After establishing the stationarity of the data series a cointegration test is conducted. Since we have used panel data in our study we conducted Pedroni's panel cointegration test (Pedroni, 1999 and 2004). The test results are reported in Tables 2 and 3. As seen in those tables, in both versions of equation, most of the test statistics that the null hypothesis of no cointegration is rejected at the conventional level of significance. This indicates presence of long run relationship among the variables in both equations. Therefore following Engle and Granger (1987), an error correction model is developed which is as follows:

$$
\begin{aligned}
& \Delta \log Y_{t}=b_{0}+b_{1} \Delta \log G_{t}+b_{2} \Delta \log M S_{t}+b_{3} \Delta \log R E_{t}+b_{4} \Delta \log R E_{t-1}+b_{5} \Delta \log R E_{t-2} \\
& +b_{6} \Delta \log \mathrm{TOT}_{t}+b_{7} E C+v_{3} \\
& \Delta \log Y_{t}=b_{0}+b_{1} \Delta \log G_{t}+b_{2} \Delta \log M S_{t}+b_{3} \Delta \log E_{t}+b_{4} \Delta \log E_{t-1}+b_{5} \Delta \log E_{t-2} \\
& +b_{6} \Delta \log R E P R_{t}+b_{7} \Delta \log R E P R_{t-1}+b_{8} \Delta \log R E P R_{t-2}+b_{9} \Delta \log T O T_{t}+b_{10} E C+v_{4}
\end{aligned}
$$

The lagged values of $R E, E$, and REPR are included to capture the short, medium, and long run effects of a change in the exchange rate on the aggregate output. In equation (3) and equation (4), $E C$ is the error correction term which is nothing but the lag of the estimated error terms from their corresponding equations (1) and (2) respectively.

The estimation of the model using panel data from different countries requires that the unobserved countryspecific variables are not correlated with the included right hand side variables. If they are correlated the model could generate misleading results. In order to address this problem we use fixed effects estimation (Pradhan, et. al. 2008). The South-east Asian economy went through a major financial crisis in 1997. In order to capture any possible effect of this crisis a dummy variable (DUMMY; 1 for 1997, 1998 and 1999 and 0 for other years) is included in both models. In the initial estimation we encountered the problem of autocorrelation in both estimations. Therefore, we estimated equations (3) and (4) with AR(1) term which are reported below in equations (5) and (6):

$$
\begin{aligned}
& \Delta \log Y_{t}=0.136 \Delta \log G E_{t}+0.058 \Delta \log M S_{t}-0.005 \Delta \log T O T_{t}-0.032 \Delta \log R E_{t} \\
& \text { (1.606) (1.69)* (0.13) (0.94) } \\
& \text { - 0.064 } \log R E_{t-1}+0.032 \Delta \log R E_{t-2}+0.005 D U M M Y-0.282 E C+0.612 A R(1) \\
& (1.73) * \quad(1.15) \quad(0.32) \quad(2.72) * * * \quad(4.06) * * * \\
& \text { Adj } R^{2}=0.26 \quad \text { D.W. }=1.83 \quad \text { F stat }=4.87 \quad n=108 \\
& \Delta \log Y_{t}=0.0 .084 \Delta \log G E_{t}+0.064 \Delta \log M S_{t}-0.008 \Delta \log T O T_{t}-0.12 \Delta \log E_{t} \\
& \begin{array}{llll}
(1.20) & (2.27)^{*} & (0.27) & (3.98) * * *
\end{array} \\
& -0.076 \Delta \log E_{t-1}+0.016 \Delta \log E_{t-2}+0.153 \Delta \log R E P R_{t}+0.26 \Delta \log R E P R_{t-1}-0.023 \Delta \log R E P R_{t-2} \\
& (1.91) * \quad(0.51) \quad(2.95) * * * \quad 0.54) \\
& \text { - } 0.002 \text { DUMMY - } 0.263 E C+0.61 A R(1)
\end{aligned}
$$


(0.18) $\quad(1.71)^{*} \quad(3.53) * * *$

Adj $R^{2}=0.604 \quad$ D.W. $=1.90 \quad$ F stat $=11.68 \quad n=108$

Equations (5) and (6) are estimated results of equations (3) and (4) respectively. The overall results of the estimation seem to be good in terms of the coefficient of determinant, the $F$-statistics and the direction of the coefficients. In both form equations the estimation of the coefficient of government expenditure $(\log G E)$ is positive but statistically insignificant at the conventional level of significance. However, it is significant at 15\% and 25\% percent critical level respectively in equation (5) and (6). The monetary variable $(\log M S)$, however, is found to be statistically significant in both of the estimates suggesting that monetary policy can be an effective macroeconomic tool in the countries under study. Both estimations could not capture any significant effect of financial crisis as indicated by insignificant coefficient of DUMM.

The focus of this study are the coefficients of the real exchange rate $(\log R E)$, the nominal exchange rate $(\log E)$, and the foreign to domestic price ratio $(\log R E P R)$. The contemporaneous effect of the real exchange rate $(\log R E)$ is negative but not significant. Its lag effect, however, is negative and statistically significant. Its two year lag becomes positive but remains insignificant. This suggests that the effect of real devaluation is neutral in the short run, contractionary in the intermediate run and remains neutral in the long run.

Equation (6) presents the regression result that decomposes the real exchange rate into the nominal exchange rate and the foreign to domestic price ratio. The results show a pattern of results similar to equation (5). The coefficients of contemporaneous, lagged as well as two period lagged nominal exchange rate $(\log E)$ are negative but statistically significant only in the short (contemporaneous) and intermediate run (one year lag). The contemporaneous effect of a change in the relative price ratio $(\log R E P R)$ is positive and statistically significant. The one year lag effect is negative and the two year lag effect is positive, but both of the coefficients are statistically insignificant.

The overall findings suggest a real depreciation or devaluation has a contractionary effect in the economy in the short and the intermediate run, but not in the long run. The contractionary effect comes from the change in nominal exchange rate, not from foreign-to-domestic price ratio.

\section{SUMMARY AND CONCLUSION}

This paper studies the effect of currency devaluation on aggregate output level in four South-East Asian countries namely, Thailand, Malaysia, Indonesia and the Philippines. An empirical model is developed for the analysis in which fiscal, monetary variables and real exchange rates are included. An alternative model which decomposes the real exchange rate into the nominal exchange rate and the foreign to domestic price ratio is also developed in order to identify whether any changes in the aggregate output is coming from nominal devaluation, relative price ratio (foreign to domestic price ratio) or both. Panel data comprised of annual time series data from 1974 to 2010 is used. In both model versions the time series properties of the panel data are diagnosed using panel unit root and panel cointegration tests prior to the estimations. An error correction model is developed since the data series are found to be stationary at the first difference level and the hypothesis of no cointegration is rejected. The model is estimated using a fixed effect estimator in order to account for the country specific effect. The estimated results suggest that the currency devaluation is contractionary in the short run, intermediate run, and but not in the long run. The results show that the contractionary effect comes from nominal devaluation, not from the foreign to domestic price ratio.

\section{ACKNOWLEDGEMENT}

An earlier version of the paper was presented in the $22^{\text {nd }}$ International Trade and Finance Association Meeting in Pisa, Italy, May 23 - 26, 2012. 


\section{AUTHOR INFORMATION}

Kamal P. Upadhyaya, Department of Economics, University of New Haven, 300 Boston Post Road, West Haven, CT 06516, USA. E-mail: kupadhyaya@ @ewhaven.edu (Corresponding author)

Robert Rainish, University of New Haven, 300 Boston Post Road, West Haven, CT 06516, USA. E-mail: rrainish@ newhaven.edu

Neetu Kaushik, Department of Economics, University of New Haven, West Haven, CT 06516. E-mail: nkaushik@newhaven.edu

Rabindra N. Bhandari, Department of ABE \&MIS, Westminster College, Fulton, MO 65251. E-mail: rabindra.bhandari@westminster-mo.edu

\section{REFERENCES}

1. Branson, H. William (1986) Stabilization, stagflation and investment incentives: the case of Kenya 197580, in Economic Adjustment and Exchange Rates in Developing Countries (Eds) S. Edwards and L. Ahamed, University of Chicago Press, Chicago.

2. Breitung, J. (2000). The Local Power of some Unit Root Tests for Panel Data, in Baltagi, B.H. (Ed.) Nonstationary Panels, Panel Cointegration, and Dynamic Panels, Elsevier, Amsterdam.

3. Connolly, M. (1983) Exchange rates, real economic activity and the balance of payments: evidence from the 1960s in, Recent Issues in the Theory of the Flexible Exchange Rates (Eds) E. Classen and P. Salin, Amsterdam, North Holland.

4. Cooper, R. (1971) Currency Devaluation in Developing Countries, in Government and Economic Development (Ed) G. Ranis, New Haven, Yale University Press.

5. $\quad$ Edwards, S. (1986) Are devaluations contractionary? Review of Economics and Statistics, vol. 68, 501-508.

6. Engle, R. and Granger, C. (1987) Cointegration and error correction: representation, estimation, and testing, Econometrica, vol. 55, 251-76.

7. Gylfason, T. and Schmid, M. (1983) Does devaluation cause stagflation?, Canadian Journal of Economics, vol. 16, 641-54.

8. Gylfason, T. and Risager, O. (1984) Does devaluation improve the current account? European Economic Review, vol. 25, 37-64.

9. Im, K.S., M.H. Pesaran and Y. Shin (2003). Testing for unit roots in heterogeneous panels, Journal of Econometrics 115, 53-74.

10. International Monetary Fund (various issues) International Financial Statistics, Washington, DC.

11. Khan, S., Mohsin, S. and Knight, M. D. (1981) Stabilization program in developing countries: a formal framework, IMF Staff Papers, vol. 28, 1-53.

12. Krugman, P. and Taylor, L. (1978) Contractionary effect of devaluation, Journal of International Economics, vol. 8, 445-56.

13. Levin, A., C.F. Lin, \& J. Chu (2002) Unit root tests in panel data: Asymptotic and finite sample properties. Journal of Econometrics 98, 1-24.

14. Lizondo, J. and P. Montiel, 1989, Contractionary Devaluation in Developing Countries: An Analytical Overview, IMF Staff Papers, vol. 36, March, pp.182-227.

15. Pedroni, P. (2004), "Panel Cointegration; Asymptotic and Finite Sample Properties of Pooled Time Series Tests with an Application to the Purchasing Power Parity Hypothesis," Econometric Theory, vol. 20, 597325.

16. Pedroni, P. (1999), "Critical Values for Cointegration Tests in Heterogeneous Panels with Multiple Regressors," Oxford Bulletin of Economics and Statistics, vol. 61, 653-670.

17. Pradhan, G., Upadhyay, M. and Upadhyaya, K. (2008), Remittances and Economic Growth in Developing Countries" European Journal of Development Research, vol. 20, 497 - 506.

18. Sawyer, C. W. and Sprinkle, R. L. (1987) "Contractionary effects of devaluation in Mexico" Social Science Quarterly, vol. 68, 885-893. 
19. Upadhyaya, K.P. and Upadhyay, M. P. (1998) Output effects of devaluation: evidence from Asia, The Journal of Development Studies, vol. 35, 89-103.

20. Upadhyaya, K.P. (1999) Currency devaluation, aggregate output, and the long run: an empirical study, Economics Letters, vol. 64, 197-202.

21. Upadhyaya, K.P., Dhakal, D. and Mixon, F. G. Jr. (2000) Exchange rate adjustment and output in selected Latin American countries, Economia Internazionale, vol. 53, 107-17.

22. Upadhyaya, K. P., Mixon, D. and Bhandari, R. (2004) Exchange rate adjustment and output in Greece and Cyprus: evidence from panel data, Applied Financial Economics, vol. 14, 1181-1185

23. Wickens, R. W. and Breusch, T. S. (1988) Dynamic specification, the long run and the estimation of transformed regression models, Economic Journal, Supplement, 189-205.

24. World Development Indicator, World Bank, Washington D.C., 2011. 


\section{$\underline{\text { NOTES }}$}

